\section{International Scientific Journal Theoretical \& Applied Science}

p-ISSN: 2308-4944 (print) $\quad$ e-ISSN: 2409-0085 (online)

Year: $2017 \quad$ Issue: $08 \quad$ Volume: 52

Published: $21.08 .2017 \quad$ http://T-Science.org

SECTION 9: Chemistry and chemical technology
Darya Sergiivna Bida Kharkiv V.N. Karazine National University, student of

Chemical Metrology Department, yurchenko@karazin.ua

Oleg Ivanovych Yurchenko Kharkiv V.N. Karazine National University, PhD, Full Professor of

Chemical Metrology Department, yurchenko@karazin.ua

Tetyana Vasylivna Chernozhuk Kharkiv V.N. Karazine National University, $\mathrm{PhD}$, Associate Professor of Inorganic Chemistry Department, tanya.chernozhuk@gmail.com

Oleksii Andriovych Kravchenko

Kharkiv V.N. Karazine National University, $\mathrm{PhD}$, Associate

Professor of Chemical Metrology Department, alekseykravch@ukr.net

\title{
VALIDATION OF THE METHODIC OF QUANTITATIVE DETERMINATION OF QUERCITIN IN THE MEDICINE "LIPOPHLAVONE, LIOPHILIZATE FOR EYE DROPS PREPARATION"
}

\begin{abstract}
Validation of methodic of HPLC quantitative determination of quercitin in the medicine "Lipophlavone, liophilizate for eye drops preparation" was carried out. The methodic was developed at first and is a part of analytical normative documentation. The obtained data for parameters, demanded for validation of quantitative determination, show us, that the methodic can be used for analytical investigation of the medicine. To treat obtained data "Chemcalc" program was used.

Key words: methodic, validation, nanotechnological liposomal medicine, Chemcalc program.

Language: English

Citation: Bida DS, Yurchenko OI, Chernozhuk TV, Kravchenko OA (2017) VALIDATION OF THE METHODIC OF QUANTITATIVE DETERMINATION OF QUERCITIN IN THE MEDICINE «LIPOPHLAVONE, LIOPHILIZATE FOR EYE DROPS PREPARATION». ISJ Theoretical \& Applied Science, 08 (52): 43-51.
\end{abstract}

Soi: http://s-o-i.org/1.1/TAS-08-52-6 Doi: crossef https://dx.doi.org/10.15863/TAS.2017.08.52.6

\section{Introduction}

At the modern stage of pharmacy development the new brunch of creation of the new medicines with antioxidant and inflammation activity is developed too. The most important natural antioxidants are bioflavonoids (rutine, quercitin, flacumine), which possess good antioxidant and anti inflammation activity due to catching of endorgenic radicals. On the base of such biflavonoid nanotechnological liposomal medicine "Lipophlavone, liophilizate for eye drops preparation" was created. The medicine consists of quercitin, phosphatidylcholine (active substances) and lactose like crioprotector. [1,p.5050;2,p. 20;3,p.15;4.p.20;5,p.17;6,p.7].
Development of methods of control of quality is part of pharmaceutical creation of medicines. To control the composition of the medicine the new methodic of qualitative determination of one of the active substance-quercitin, using high performance liquid chromatography (HPLC) method was developed. HPLC is universal and high effective method in analytical chemistry, because of it is widely used in modern analytical methodic. [7,p.75; 8,p.30].

HPLC method except of selectivity, is different from TLC and spectrophotometry in its sensibility. Because of we have small amount of quercitin in our medicine, we should use HPLC method. We can not use big samples of the medicine because of 
nonhomogeneous distribution of quercitin in the samples. In this case we should use sample of the medicine from one vessel because at low concentrations an error of measurement makes contribution in the obtained results.

According to demands SPU 2.0 (State Pharmacopoeia of Ukraine) to carry out validation of methodic of quantitative determination in medicines forms we should estimate the next characteristics: accuracy, that included convergence and intralaboratory accuracy, selectivity (specify), linearity, diapason of use, robustness (stability of the methodic to changes) [10,p.20;12,p 5].

The purpose of the work is: to determine use of developed methodic to analytical investigation of the medicine, with use of "Chemcalc" program.

\section{Experimental}

Liquid chromatography HPLC Shimadzu LC 20AD, detector LT-ELSD SEDEX 85; dozen pipettes Vitlab from 100 to $1000 \mathrm{mkl}$; laboratory scale Kern $82 \mathrm{~g} \backslash 320 \mathrm{~g}, d=0.01 \mathrm{mg} / 0.1 \mathrm{mg}$; volumetric flasks Simax, of 10 and $100 \mathrm{ml}$ volume; device to obtain high purified water Millipore/Millipore Direct-Q SUV were used for analysis.

Conditions of chromatography were: column Waters Xbridge Shield RP18 $5 \mathrm{mkm} \times 250 \mathrm{~mm} \times 4.6$ $\mathrm{mm}$; temperature of column was $55^{\circ} \mathrm{C}$; mobile phase $\mathrm{B}$ : metanole-acetonitrile, phase A $1 \%$ water solution of acetic acid; flows rate is $1 \mathrm{ml} / \mathrm{min}$ : volume of injected sample is $10 \mathrm{mkl}$; detection; wave lengths of detection is $371 \mathrm{~nm}$. An algorithm of carrying out chromatography is in the Table 1 .

Investigated solution: to the vessel with the medicine, that consists of lipophilizated powder with contain of quercitin $0,75 \mathrm{mg}$, phosphatidylcholine $27,5 \mathrm{mg}$ and lactose $40 \mathrm{Mr}$, was added $2 \mathrm{ml}$ of phase $\mathrm{B}$, mixed up to total dissolution. The contain of the vessel is placed into volumetric flack of $10 \mathrm{ml}$ volume, brought up to the mark by $\mathrm{B}$ phase and mixed. The solution is filtered through PTFE membrane with porous diameter of $0.45 \mathrm{mkm}$.

Compensation solution: the sample of $0.1126 \mathrm{~g}$ of standard quercitin dyhydrate (Quercetin dihydrate CRS batch2, 90.5\% $\quad \mathrm{C}_{15} \mathrm{H}_{10} \mathrm{O}_{7}$, EC no 204-187-1, RTECS No LK8950000) was placed into volumetric flack of $100 \mathrm{ml}$ volume, dissolved in $70 \mathrm{ml}$ of $\mathrm{B}$ phase and brought up to the mark by B phase and mixed. $0.75 \mathrm{ml}$ of quercitin dyhydrate solution is placed into volumetric flack of $10 \mathrm{ml}$ volume and dissolved in B phase. [9,p.30;11,p.10]

\section{Results and discussion}

At the first stage of our work an availability of chromatography system was estimated.

The results of availability of chromatography system are in the Table 2 (data by Shimadzu LCsolution Analysis Report).
According to demands of SPU 2.0 the results from table 2 approve an availability of chromatography system.

At the second stage of our work selectivity of methodic was estimated. There are only peak of quercetin is observed in this system. Peaks of phosphatidylcholine and lactose are not observed. It was proved by absence of phosphatidylcholine and lactose peaks on placebo chromatogram (and phosphatidylcholine and lactose solution in phase B). Spectral purification of the quercitin peak, obtained with use of diode-matrix detector for investigated and comparison solutions was checked up. An example of placebo chromatogram is on 1(a) Figure. Examples of chromatograms and peaks spectra for compensation and investigated solutions are on Fig. 1(b). And Fig. 1(c) respectively. Peak cleanness of quercitin in comparison solutions is observed at wave lengths $370.57 \mathrm{~nm}$ ( Fig. 1(b)). Peak cleanness of quercitin in investigated solutions is observed at wave lengths $370.50 \mathrm{~nm}$ ( Fig. 1(c)).

At the third stage of our work an accuracy of the methodic was estimated. An accuracy of the methodic was checked by establishing of comparison between well known true value (external international standard) and obtained value (an average value), using the methodic in a number of parallel measurements. An analysis of a number of samples, prepared according to external international standard Quercitin dihydrate CRS with well known concentrations of quercitin in three parallels of every sample. Five standard samples with well known concentration of quercitin were prepared from solution of standard quercitin sample. Also an analysis of samples, prepared from quercitin dihydrate with the same concentrations was carried out. Five standard samples with well known quercitin concentration were prepared from compensation solution. Five investigated samples were prepared from quercitin solution with concentration $1 \mathrm{mg} \backslash \mathrm{ml}$.

The results of an accuracy of the methodic are in Table 3.

Result: The obtained result $98.2 \pm 0.1$ is not exceed an error of the methodic, described in analytical documentation in the diapason of use "Lipoflavone-nano" medicine, like 100 $\pm 10 \%$ (from 0.67 up to $0.83 \mathrm{mg}$ in the vessel).

At the fourth stage of our work linearity of the methodic was estimated.

To prove linear dependence of peak square from concentration in the solution were prepared 5 solutions with quercitin concentrations $0,6 \mathrm{mg} / \mathrm{ml}$, 0,7 mg/ml, 0,8 mg/ml, 0,9 mg/ml, $1 \mathrm{mg} / \mathrm{ml}$. To do it, 5 precise samples of Quercitin standard (Quercitin dihydrate CRS batch 2, 90.5\% $\mathrm{C}_{15} \mathrm{H}_{10} \mathrm{O}_{7}$, EC no 204187-1, RTECS No LK8950000) in the diapason from $75 \%$ to $125 \%$ from contain in the medicine were taken and solutions in the B phase were prepared. 
Every solution was analyzed trice and coefficients of linear regression were determined.

The results of linearity of the methodic are on pic. 2 and table 4 .

At the fifth stage of our work the diapason of use of the methodic was estimated. Diapason of use of the methodic at quantitative determination in medicines is from 80 up to $120 \%$ from nominal content of active substance. Content of quercitin, according to analytical normative documentation of the medicine, is in diapason from 0,67 up to $0,83 \mathrm{mg}$ in the vessel or $0,75 \mathrm{mg} \pm 10 \%(100 \% \pm 10 \%)$, what is conformed with demands according to medicines.

At the sixth stage of our work an accuracy of the methodic was estimated. To determine accuracy of the method of quantitative determination, the investigated solution was chromatographed 5 times in one day according to the methodic. The criteria of accuracy is relative standard deviation. The results of accuracy estimation of the methodic are in the Table 4.

Relative standard deviation is $\mathrm{Sr}, \%=0,145$. At the step of validation, laboratory accuracy according to the given conditions (equipment, climate, reagents, etc.) was determined.

At the seventh stage convergence of the methodic was estimated. To determine convergence of the results of analysis (as index of stability of the used HPLC method) 3 solutions with 2 parallel samples with concentrations of quercitin in diapason from 80 up to $120 \%$ were chromatographed. The results of estimation of convergence of the methodic are in the Table 5.

At the eights stage of our work robustness (stability of the methodic to changes) was estimated. To check robustness of chromatography we should determine stability of solutions with time, and an influence of subjective factors should be determined.
An influence of subjective factors was not proved by our investigation of laboratory accuracy.

Using developed by us software «ChemCalck», calculations of quantitative determination of quercitin in the medicine "Lipophlavone, liophilizate for eye drops preparation" were done. The software was developed on $\mathrm{C \#}$ programming language with use Windows Forms и Entity Framework Code First technologies.

At first were created three templates to carry out calculations:

- Parametrical, contained all of the parameters of chromatography.

- Template, contained all of information about sample preparation.

- General template, contained all information about sample and connect all of templates into one.

After we put our samples in the general database and with created template did treatment of the obtained experimental data.

As a result we obtained quantitative content of quercitin in the samples and statistic information about it. Use these results we can make an account, included all information about carried out analysis.

\section{Conclusions}

Validation of developed by us methodic of quantitative determination of quercitin in the medicine "Lipophlavone, liophilizate for eye drops preparation" was carried out. The methodic was done with use of HTML on chromatograph of Shimadzu company and diode-matrix detector Waters Xbridge Shield RP18 $5 \times 250 \mathrm{~mm} \times 4.6 \mathrm{mkm}$. It was shown that the methodic can be used for analytical investigations of "Lipophlavone, liophilizate for eye drops preparation. It was proved by using developed by us a "Chemcalc" software.

\section{An algorithm of carrying out chromatography}

Table 1

\begin{tabular}{|c|c|c|c|}
\hline Time $(\mathrm{min})$ & $\begin{array}{c}\text { Flow } \\
(\mathrm{ml} / \mathrm{min})\end{array}$ & $\begin{array}{c}\text { Mobile phase A } \\
(\% \text { vol. })\end{array}$ & $\begin{array}{c}\text { Mobile phase B } \\
(\% \text { vol. })\end{array}$ \\
\hline 0 & 1.0 & 40 & 60 \\
\hline 19.0 & 1.0 & 40 & 60 \\
\hline 20.0 & 1.0 & 10 & 90 \\
\hline 27.0 & 1.0 & 10 & 60 \\
\hline 28.0 & 1.0 & 40 & 60 \\
\hline
\end{tabular}




\begin{tabular}{|c|c|c|c|c|c|c|}
\hline Impact Factor: & $\begin{array}{l}\text { ISRA (India) } \\
\text { ISI (Dubai, UAE } \\
\text { GIF (Australia) } \\
\text { JIF }\end{array}$ & $\begin{array}{r}=1.344 \\
=0.829 \\
=0.564 \\
=1.500\end{array}$ & $\begin{array}{l}\text { SIS (USA) } \\
\text { PИНЦ (Russia) } \\
\text { ESJI (KZ) } \\
\text { SJIF (Morocco) }\end{array}$ & $\begin{array}{l}=0.912 \\
=0.234 \\
=\mathbf{3 . 8 6 0} \\
=\mathbf{2 . 0 3 1}\end{array}$ & $\begin{array}{l}\text { ICV (Poland) } \\
\text { PIF (India) } \\
\text { IBI (India) }\end{array}$ & $\begin{array}{l}=6.630 \\
=1.940 \\
=4.260\end{array}$ \\
\hline
\end{tabular}

The results of availability of chromatography system

\begin{tabular}{|c|c|c|c|c|c|}
\hline $\begin{array}{c}\text { Compensation } \\
\text { solution №1 }\end{array}$ & $\begin{array}{c}\text { Retention } \\
\text { time, min }\end{array}$ & Peak square & Peak height & Tailing factor & $\begin{array}{c}\text { Number of } \\
\text { theoretical plates }\end{array}$ \\
\hline 1 & 9.030 & 2788725 & 107146 & 6.848 & 11.445 \\
\hline 2 & 9.034 & 2776390 & 106326 & 6.731 & 11.232 \\
\hline 3 & 9.034 & 2775399 & 106380 & 6.624 & 11.360 \\
\hline Mean values: & & 2780171 & & & Number of \\
\hline $\begin{array}{c}\text { Investigated } \\
\text { solution № 1, }\end{array}$ & $\begin{array}{c}\text { Retention } \\
\text { time, min }\end{array}$ & Peak square & Peak height & Tailing factor & 11.008 \\
\hline 1 & 9.060 & 2693526 & 103435 & 6.773 & 11.072 \\
\hline 2 & 9.056 & 2677276 & 101939 & 6.816 & 11.012 \\
\hline 3 & 9.038 & 2681352 & 102094 & 6.735 & \\
\hline \multicolumn{7}{|l|}{$\mathbf{2}$ ( USP38/NF33 Dietary Suplements: Quercitin) [13]. } \\
\hline
\end{tabular}

Table 3

The results of an accuracy of the methodic $\left(n=9, P=0.95, S_{r}=0.36 \%\right)$.

\begin{tabular}{|c|c|c|c|}
\hline $\begin{array}{c}\text { № of } \\
\text { sample }\end{array}$ & $\begin{array}{c}\text { Quercitin content in standard } \\
\text { solution } \mathrm{mg} / \mathrm{ml} \text { «injected» }\end{array}$ & $\begin{array}{c}\text { Quercitin substansion content in } \\
\text { investigated solution } \mathrm{mg} / \mathrm{ml} \text { «found } \\
\text { out» }\end{array}$ & $\begin{array}{c}\text { Quercitin content «found } \\
\text { out» from «injected»,\% }\end{array}$ \\
\hline 1 & 0.068 & 0.066 & 98.18 \\
\hline 2 & 0.079 & 0.077 & 98.13 \\
\hline 3 & 0.090 & 0.088 & 98.15 \\
\hline 4 & 0.101 & 0.099 & 98.09 \\
\hline 5 & 0.113 & 0.111 & 98.37 \\
\hline Mean value: & & 98.184 \\
\hline
\end{tabular}

Table 4

The results of estimation of linearity and accuracy.

\begin{tabular}{|c|c|c|c|}
\hline \multicolumn{2}{|c|}{ Linearity of the methodic } & \multicolumn{2}{c|}{$\begin{array}{c}\text { Accuracy of the methodic } \\
\left(n=5, P=0.95, S_{r}=0.145 \%\right)\end{array}$} \\
\hline $\begin{array}{c}C \text { (of standard } \\
\text { solution), } \mathrm{mg} / \mathrm{ml}\end{array}$ & An average peak square & № & Content of quercitin, mg in the vessel \\
\hline 0.61 & 2049968.67 & 1 & 0.75 \\
\hline 0.71 & 2441709.67 & 2 & 0.76 \\
\hline 0.82 & 2800191.33 & 3 & 0.76 \\
\hline 0.92 & 3158978.33 & 4 & 0.77 \\
\hline 1.02 & 3560322 & 5 & 0.75 \\
\hline
\end{tabular}

The results of estimation of convergence of the methodic

Table 5

\begin{tabular}{|c|c|c|c|c|}
\hline № of injection & Peak square & $\begin{array}{c}\text { An average peak } \\
\text { square }\end{array}$ & $\begin{array}{c}\text { Qercetin content , } \\
\mathrm{mg}\end{array}$ & $\begin{array}{c}\text { Qercetin content from } \\
\text { nominal, \% }\end{array}$ \\
\hline \multicolumn{7}{|c|}{ Content of quercitin 80\% from nominal one $\left(S_{r}=1.17 \%\right)$} \\
\hline 1 \\
\hline 2 & 2135727 & 2135989 & 0.61 & 81.3 \\
\hline \multicolumn{7}{|c|}{ Content of quercitin 100\% from nominal one $\left(S_{r}=1.77 \%\right)$} \\
\hline 1
\end{tabular}




\begin{tabular}{l|lr|ll|ll} 
& ISRA (India) & $=\mathbf{1 . 3 4 4}$ & SIS (USA) & $=\mathbf{0 . 9 1 2}$ & ICV (Poland) & $=\mathbf{6 . 6 3 0}$ \\
Impact Factor: & ISI (Dubai, UAE) & $=\mathbf{0 . 8 2 9}$ & PVHIL (Russia) $=\mathbf{0 . 2 3 4}$ & PIF (India) & $=\mathbf{1 . 9 4 0}$ \\
& GIF (Australia) & $=\mathbf{0 . 5 6 4}$ & ESJI (KZ) & $=3.860$ & IBI (India) & $=\mathbf{4 . 2 6 0}$ \\
& JIF & $=\mathbf{1 . 5 0 0}$ & SJIF (Morocco) & $=\mathbf{2 . 0 3 1}$ & & \\
\hline
\end{tabular}

\begin{tabular}{|c|c|c|c|c|}
\hline 2 & 2677276 & & \\
\hline \multicolumn{3}{|c|}{ Content of quercitin $120 \%$ from nominal one $\left(S_{r}=0.79 \%\right)$} & \\
\hline 1 & 3176012 & 3111484.5 & 0.89 & 118.7 \\
\hline 2 & 3046957 & & & \\
\hline
\end{tabular}

An average relative standard deviation of peaks squares is $1,24 \%$.

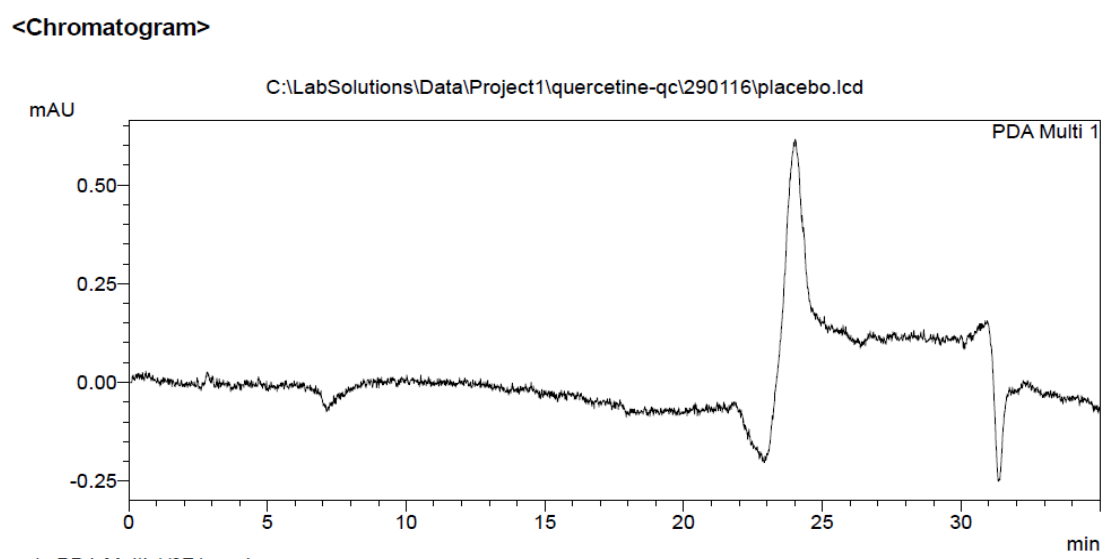

1 PDA Multi $1 / 371 \mathrm{~nm} 4 \mathrm{~nm}$

$<$ Chromatogram>

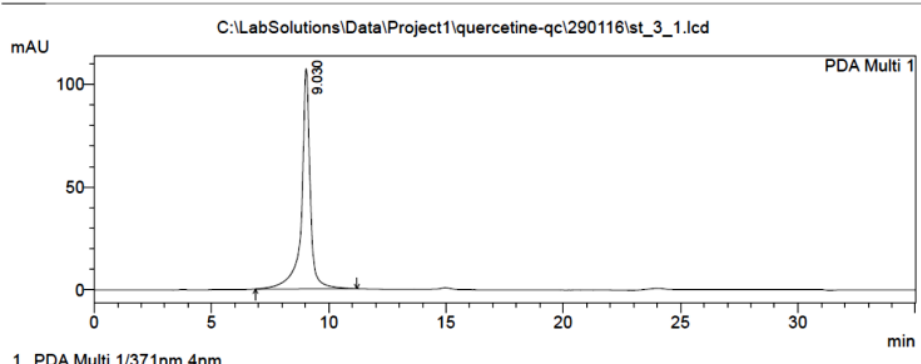

1 PDA Multi $1 / 371 \mathrm{~nm} 4 \mathrm{~nm}$

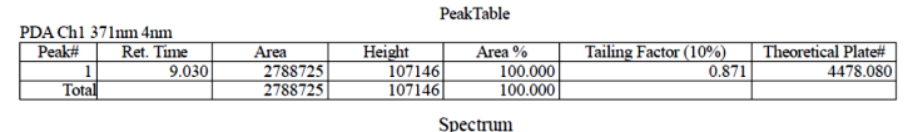

$\begin{array}{ll}206 / 371 / 255285 / 761 / 203 \\ \text { Peak\# } \\ \text { Retention Time } & : 9.030\end{array}$

$\mathrm{mAU}$

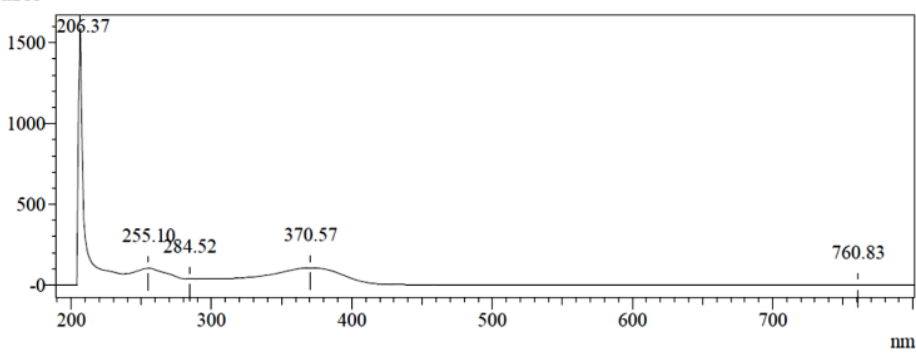

$b$ 


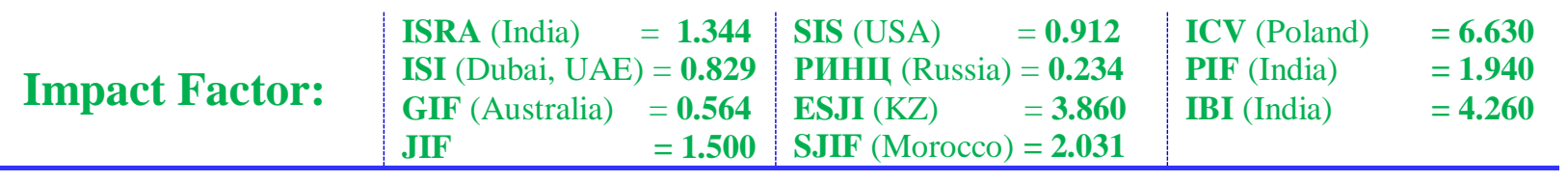

$<$ Chromatogram>
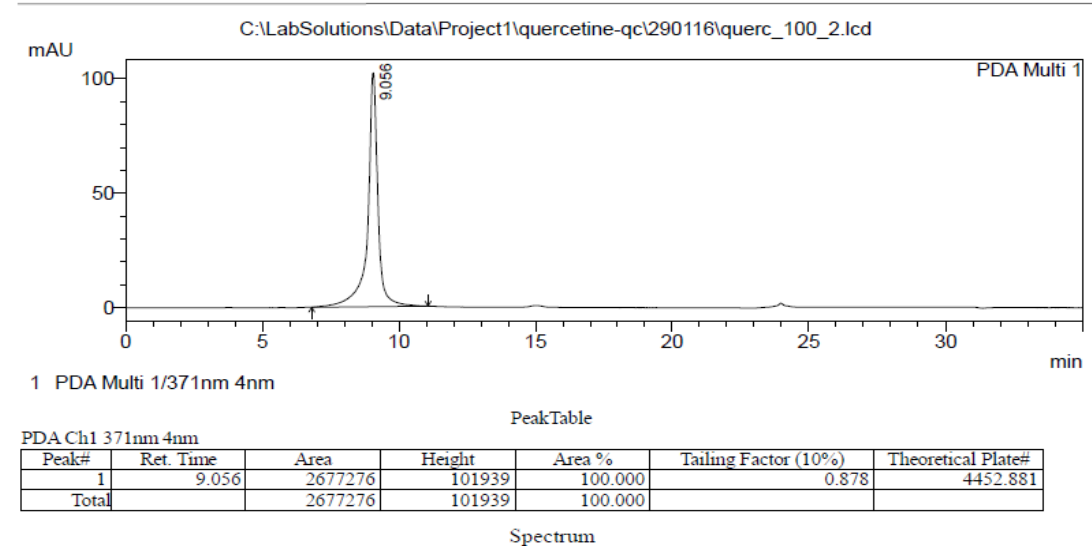

$$
\begin{aligned}
& \text { 206/371/255285/486/203 } \\
& \text { Peak\# } \\
& \text { Retention Time }
\end{aligned}
$$

Spectrum

mAU

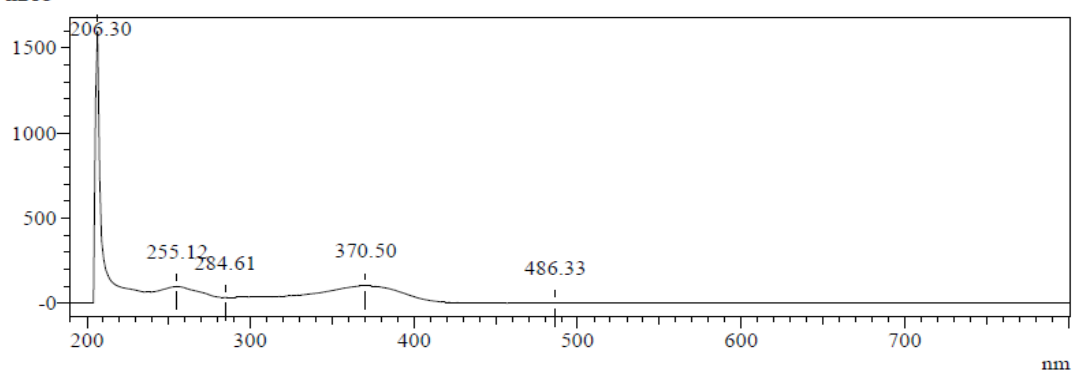

$a$

\section{$<$ Chromatogram >}

$\mathrm{mV}$

C:ILabSolutions|Data|Project1Vlipids 220117 Ivalid $\mid$ placebo.Icd

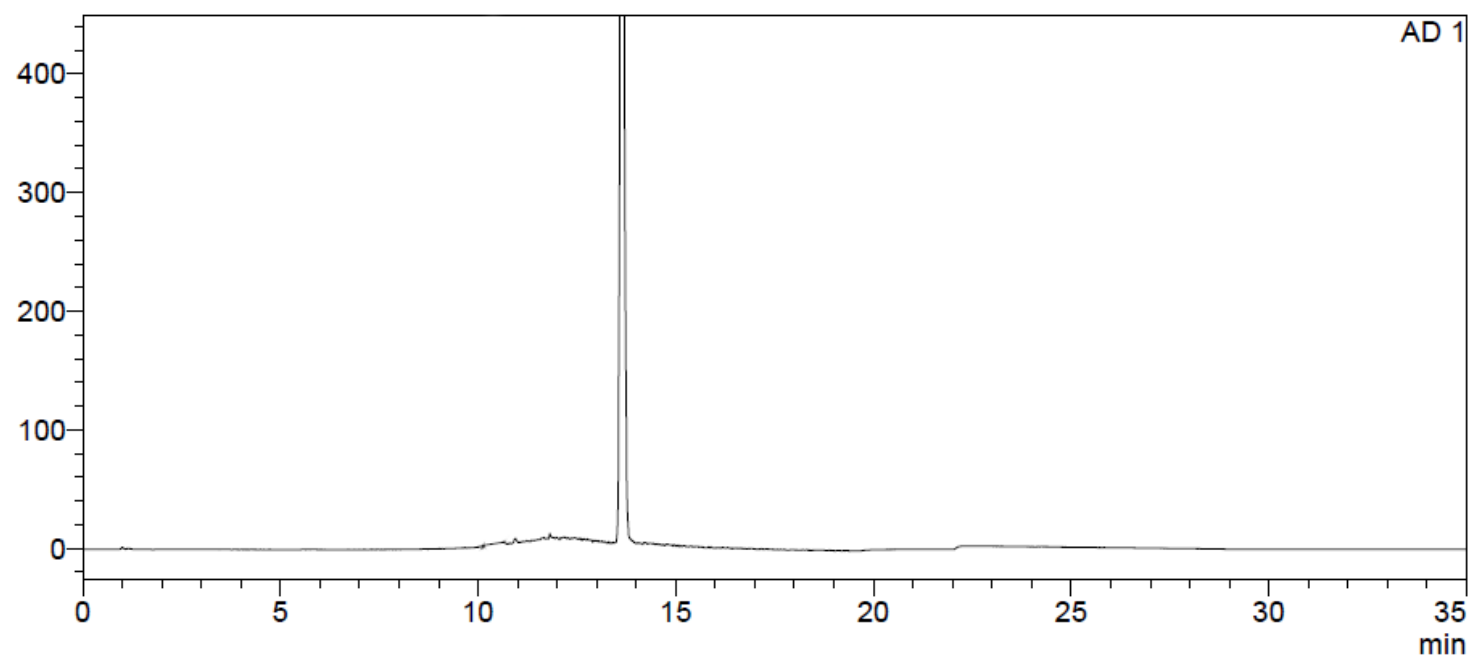

$1 \mathrm{AD} 1 /$ 


\begin{tabular}{|c|c|c|c|c|c|c|}
\hline Impact Factor: & $\begin{array}{l}\text { ISRA (India) } \\
\text { ISI (Dubai, UAE } \\
\text { GIF (Australia) } \\
\text { JIF }\end{array}$ & $\begin{array}{r}=1.344 \\
=0.829 \\
=0.564 \\
=1.500\end{array}$ & $\begin{array}{l}\text { SIS (USA) } \\
\text { PИНЦ (Russia) } \\
\text { ESJI (KZ) } \\
\text { SJIF (Morocco) }\end{array}$ & $\begin{array}{l}=0.912 \\
=0.234 \\
=\mathbf{3 . 8 6 0} \\
=\mathbf{2 . 0 3 1}\end{array}$ & $\begin{array}{l}\text { ICV (Poland) } \\
\text { PIF (India) } \\
\text { IBI (India) }\end{array}$ & $\begin{array}{l}=6.630 \\
=1.940 \\
=4.260\end{array}$ \\
\hline
\end{tabular}

$<$ Chromatogram $>$

$\mathrm{mV}$

C:ILabSolutions $\mid$ Data|Project1Vlipids $|220117|$ validlst_3_2.Icd

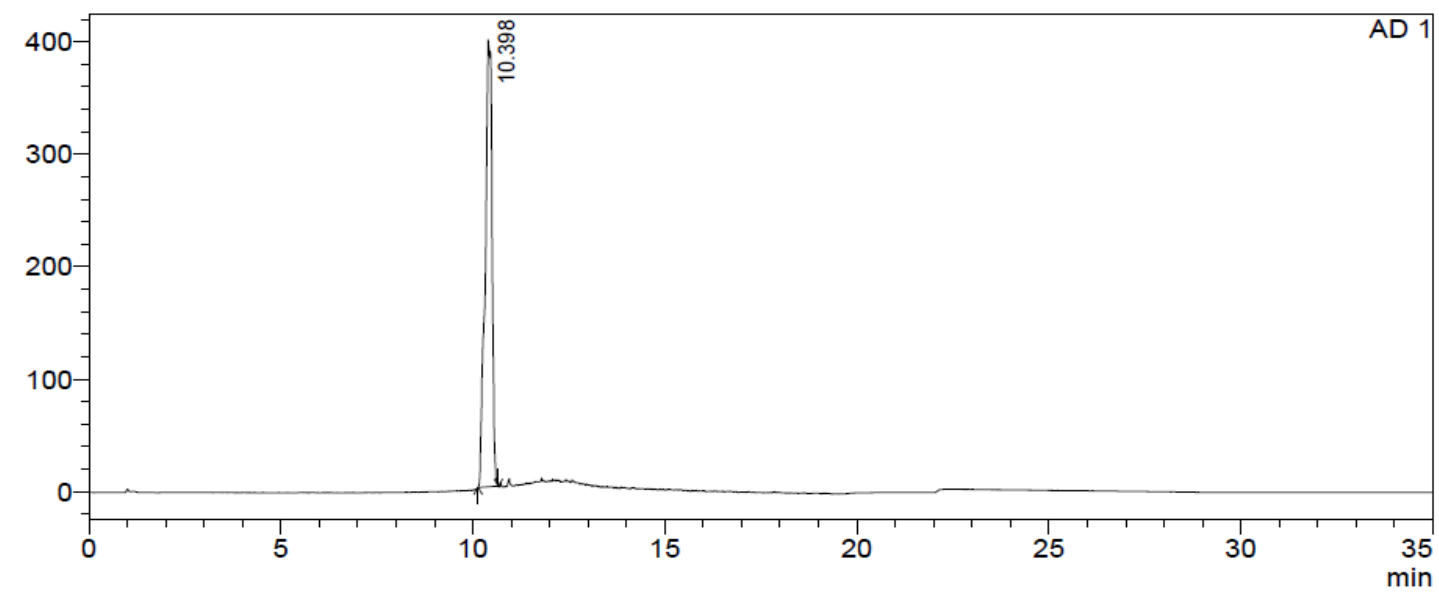

$1 \mathrm{AD} 1 /$

PeakTable

ELSD Ch1
\begin{tabular}{|r|r|r|r|r|r|r|}
\hline Peak\# & Ret. Time & \multicolumn{1}{|c|}{ Area } & Height & Area $\%$ & Theoretical Plate\# & Tailing Factor $(10 \%)$ \\
\hline 1 & 10.398 & 4943115 & 397638 & 100.000 & 21366.110 & 0.932 \\
\hline Total & & 4943115 & 397638 & 100.000 & & \\
\hline
\end{tabular}

$<$ Chromatogram>

c

$\mathrm{mV}$

C:ILabSolutions|Data\Project1Yipids|220117/validVipoflavon nano_100_1.Icd

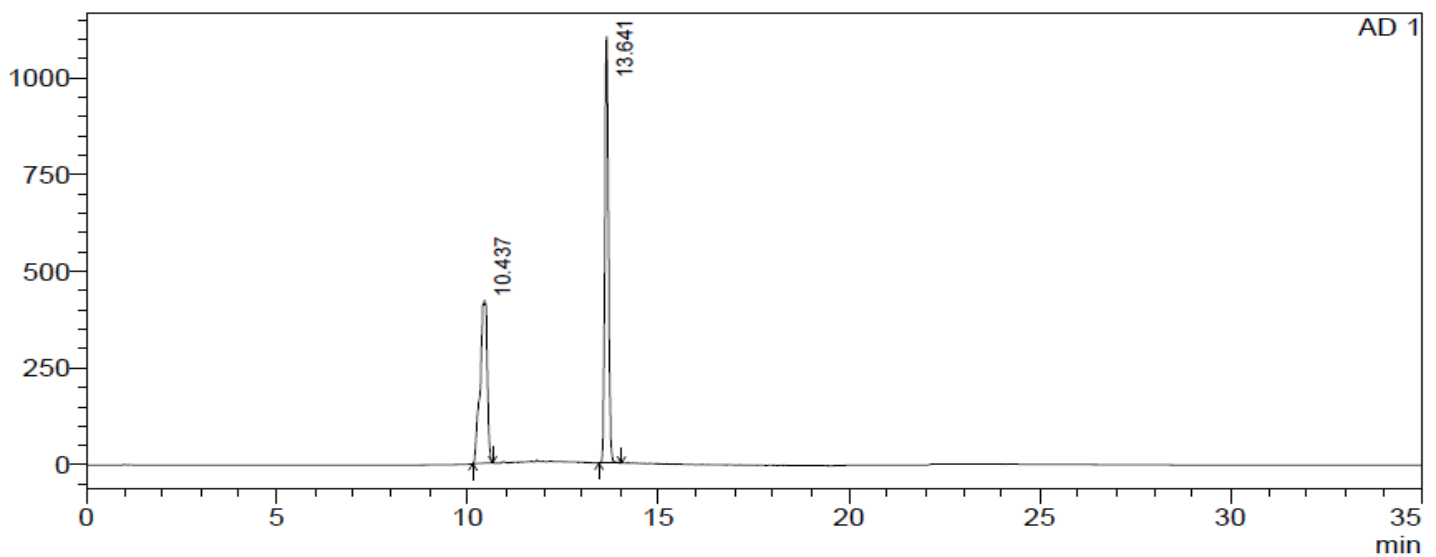

$1 \mathrm{AD} 1 /$

PeakTable

ELSD Ch1
\begin{tabular}{|r|r|r|r|r|r|r|}
\hline Peak\# & Ret. Time & Area & Height & Area \% & Theoretical Plate\# & Tailing Factor (10\%) \\
\hline 1 & 10.437 & 5458291 & 421200 & 42.667 & 20182.173 & 0.804 \\
\hline 2 & 13.641 & 7334544 & 1101607 & 57.333 & 89475.595 & \\
\hline Total & & 12792835 & 1522807 & 100.000 & & 1.103 \\
\hline
\end{tabular}

\begin{tabular}{|r|}
\hline Width at 50\% Height \\
\hline 0.182 \\
\hline 0.102 \\
\hline
\end{tabular}

Figure 1 - Chromatogram of placebo $(a)$, chromatogramme and spectra of quercitin peak of compensation solution $(b)$, of investigated solution $(c)$. 


\begin{tabular}{l|lr|ll|ll} 
& ISRA (India) & $=\mathbf{1 . 3 4 4}$ & SIS (USA) & $=\mathbf{0 . 9 1 2}$ & ICV (Poland) & $=\mathbf{6 . 6 3 0}$ \\
Impact Factor: & ISI (Dubai, UAE) $=\mathbf{0 . 8 2 9}$ & PUHЦ (Russia) $=\mathbf{0 . 2 3 4}$ & PIF (India) & $=\mathbf{1 . 9 4 0}$ \\
& GIF (Australia) & $\mathbf{0 . 5 6 4}$ & ESJI (KZ) & $=\mathbf{3 . 8 6 0}$ & IBI (India) & $\mathbf{= 4 . 2 6 0}$ \\
& JIF & $=\mathbf{1 . 5 0 0}$ & SJIF (Morocco) & $\mathbf{2 . 0 3 1}$ & & \\
\hline
\end{tabular}

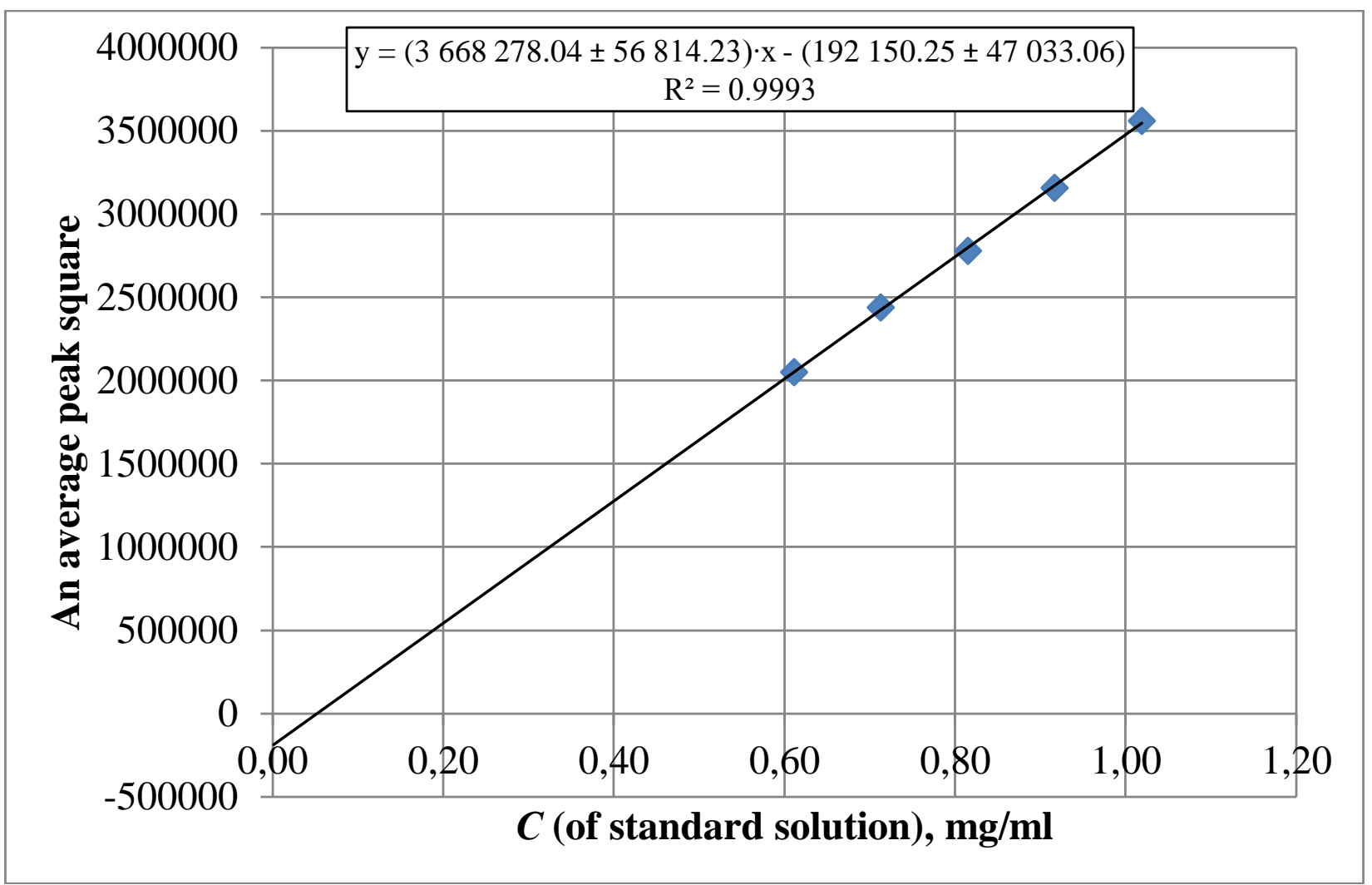

Figure 2 - Dependence of the average peak square from standard solution concentration to estimate linearity of the methodic.

\section{References:}

1. Gholam A. (2005) Advanced Drug Delivery Reviews. 2005, V. 57, pp. 2047-2052.

2. Shul'ga S.M. (2013) Biothechnologia acta. 2013, V. 6, pp. 19-40.

3. Krasnopol'skiy Yu.M., Stepnov A.E., Shvec V.I. (2011) Ukr. biofarm. jurn. 2011, V. 3, pp.10-18.

4. Shvec V.I., Krasnopol'skiy Yu.M. (2008) Provizor. 2008, V. 3, pp. 18-24.

5. (2009) Reestr lekarstvenny'h sredstv RLS $®$ 2.3.5. Antioksidanty': spravochnik. Moscow, 2009, $275 \mathrm{p}$.

6. (2017) AND Lipoflavon UA/3581/01/01

7. Yashin Ya., Vedenin A., Yashin A. (2015) Analitika. 2015, V 2.- pp. 70-84.

8. (2011) Analiticheskaya himiya V sozdanii, standartizacii i kontrole kachestva lekarstvenny'h sredstv: v 3-h tomah na russkom yazy'ke. T. 2. / [Pod red. chlen-kor. NAN Ukrainy' V.P. Georgievskogo], Har'kov: «TMT», 2011, 474 p.

9. Beregovy'h V.V. (2008) Validaciya analiticheskih metodik dlya proizvoditeley lekarstv . Moscow, Litterra, 2008, 132 p.

10. E`rmer Y., Miller D.H. (2013) Validaciya metodik $\mathrm{v}$ farmacevticheskom analize.Moscow: gr. kom. VIALEK, 2013, 350 p.

11. (2015) Derjavna Farmakopeya Ukraini / Derjavne pi'dprie"mstvo «Naukovo-ekspertniy farmakopeyniy centr». - 2-e vid. T.1. - Harki'v: DP «Ukrai`ns'kiy naukoviy farmakopeyniy centr yakosti' li'kars'kih zasobi'v», 2015, 131 p. 


\begin{tabular}{l|lr|ll|ll} 
& ISRA (India) & $=\mathbf{1 . 3 4 4}$ & SIS (USA) & $=\mathbf{0 . 9 1 2}$ & ICV (Poland) & $=\mathbf{6 . 6 3 0}$ \\
Impact Factor: & ISI (Dubai, UAE) $=\mathbf{0 . 8 2 9}$ & PUHЦ (Russia) $=\mathbf{0 . 2 3 4}$ & PIF (India) & $=\mathbf{1 . 9 4 0}$ \\
& GIF (Australia) & $\mathbf{0 . 5 6 4}$ & ESJI (KZ) & $=3.860$ & IBI (India) & $=\mathbf{4 . 2 6 0}$ \\
& JIF & $=\mathbf{1 . 5 0 0}$ & SJIF (Morocco) & $=\mathbf{2 . 0 3 1}$ & & \\
\hline
\end{tabular}

12. (2015) Derjavna Farmakopeya Ukrai ni / Derjavne pi'dprie"mstvo «Naukovo-ekspertniy farmakopeyniy centr». - 2-e vid. T.1. - Harki'v: DP «Ukrai'ns'kiy naukoviy farmakopeyniy centr yakosti' li'kars'kih zasobi'v», 2015, 1128 p.
13. (2016) U.S. Pharmacopeia National Formulary, USP38/NF33, through Second Supplement, Official Dec.1, 2015 to Apr.30, 2016, Dietary Supplements: Quercitin. 